\title{
Fine litter accumulation in Central Amazonian Tropical Rainforest canopy
}

\author{
Fabiana Rita do CO UTO O-SAN TOS¹, Flávio J. LUIZÃO² \\ ABSTRACT
}

Fine litter dynamics within the canopy dif er from litter dynamics on the forest foor for reasons such as dif erences in microclimate, substrate, disturbancelevel, stratum inf uenceand decomposition rates. T isstudy is thef rst attempt to quantify the f ne litter accumulated in the canopy of Central Amazonian forests. We compared the canopy litter accumulation to $f$ ne litter-layer on forest $f$ oor and to other forests and also investigated which were the mostly accumulated litter omponents. We found that Central Amazonian Rainforest intercepts greater $\mathrm{f}$ ne litter in the canopy ( $294 \mathrm{~g}^{\mathrm{m}} \mathrm{m}^{-2}$ ) compared to other forest formations with higher winds speed as in a Costa Rican Cloud Forest $\left(170 \mathrm{~g} . \mathrm{m}^{-2}\right)$. T e mean canopy $\mathrm{f}$ ne litter accumulated at the end of the dry season was less than a half of that on soil surface $\left(833 \mathrm{~g}^{\mathrm{m}} \mathrm{m}^{-2}\right)$ and the f ne wood component dominates the canopy samplings (174 g.m-2) while leafy component predominate on soil surface litter (353 g.m.-2).

KEYwORDS: C anopy access; C anopy litter; Litterfall; Rope techniques; Soil litter layer.

\section{Acúmulo de liteira fina no dossel de uma Floresta Tropical na Amazônia Central}

\section{RESUMO}

A dinâmica da liteira f na no dossel difere da dinâmica no chão da f oresta por razões como diferenças no microclima, tipo de substrato, taxas de decomposição, distúrbios e inf uência dos estratos. Esta é a primeira tentativa de quantif car a liteira $\mathrm{f}$ na acumulada no dossel das $\mathrm{f}$ orestas da Amazônia Central. Comparamos o acúmulo da liteira no dossel com a camada de liteira do chão da foresta e com outros tipos def orestas e investigamos quais componentes da liteira acumularam em maiores quantidades. A f oresta estudada na Amazônia Central interceptou uma maior quantidade de liteira no dossel (294 g. $\mathrm{m}^{-2}$ ) do que outras forestas com maior inf uência dos ventos, como na Costa Rica (170 g.m². $)$. A média de liteira no dossel no $\mathrm{f} \mathrm{m}$ da estação seca foi menos da metade da acumulada sobre o solo $\left(833 \mathrm{~g} \cdot \mathrm{m}^{-2}\right)$. O s galhos $\mathrm{f}$ nos dominaram nas amostras do dossel (174 g.m-2) enquanto as folhas predominaram na liteira sobre o solo (353 g.m-2).

PALAVRAS-chaVe: A cesso ao dossel; Liteira de dossel; Q ueda deliteira; Técnica de escalada por cordas; C amada deliteira do solo.

1 Instituto Nacional de pesquisas da Amazônia (INPA); E-mail: couto.santos@gmail.com

2 Instituto Nacional de pesquisas da Amazônia (INPA); E-mail: fluizao@inpa.gov.br 
As the awareness on environmental issues accelerates, including the biosphere-atmosphere interactions, studies of forest canopies become essential to our understanding of biodiversity, global atmospheric changes, and forest conservation. $T$ e development of canopy access methods has enabled scientists to conduct quantitative research in tree crowns, shifting the biological canopy science from a descriptive autoecology of specif $\mathrm{c}$ individuals to a complex ecosystem approach (Lowman \& Wittman 1996).

Fine litter dynamics within the canopy may dif er from litter dynamics on the forest foor for many reasons such as dif erences in microclimate, substrate, disturbance level, stratum influence, decomposition rates, among others (Nadkarni \& M atelson 1991). Despite several studies evaluating litterfall and litter accumulation on the forest $f$ oor, there are just a few works published on the amounts, characteristics or dynamics of suspended leaf litter in subcanopy (Alvarez-Sanchez \& Guevara 1999; D earden \& Wardle 2008) and within tree canopy crowns (N adkarni \& M atelson 1991; Nadkarni et al. 2004). To the best of our knowledgethis study is the f rst attempt to quantify $f$ nelitter accumulated in thecanopy of a Central Amazonian Rainforest, with thefollowing questionsaddressed: (1) H ow accumulated canopy litter in this type of forest can be compared to $f$ ne litter-layer on forest foor and to other tropical forests? (2) Which components of the f ne litter are mostly accumulated within tree canopy in Amazonian Forests?

$T$ is study was carried out in the Cuieiras Reserve of the $\mathrm{N}$ ational Institute for Amazonian Research (IN PA), located $60 \mathrm{~km}$ north from $M$ anaus $\left(2^{\circ} 35^{\prime} \mathrm{S}, 60^{\circ} 06^{\prime} \mathrm{W}\right)$, during the end of the dry season, from $\mathrm{O}$ ctober to $\mathrm{N}$ ovember 2008. T e climate type is " $\mathrm{Am}$ " in the Köppen classif cation with total annual rainfall about 2,700 $\mathrm{mm}$ and the rainiest months from D ecember to $\mathrm{M}$ ay and driest from August to $\mathrm{N}$ ovember. D aily mean relative humidity varies from $75 \%$ to $92 \%$ throughout the year (A raújo et al. 2002). M ean annual temperature is 26.7 ${ }^{\circ} \mathrm{C}$ with average monthly air temperature varying between 24 ${ }^{\circ} \mathrm{C}$ and $27{ }^{\circ} \mathrm{C}$ (Leopoldo et al. 1987).

To estimate the canopy fine litter accumulation we collected the f ne litter (sensu Proctor 1983, comprising leafy and reproductive materials, plus wooden material with diameters $\leq 2 \mathrm{~cm}$ ) resting on accessible branches segments within $3 \mathrm{~m}$ from the central trunk on $\mathrm{f}$ ve trees with diameter at breast height (D BH) larger than $35 \mathrm{~cm}$ and possible to be climbed by rope techniques. D espite recent advances in techniques, access to the upper canopy remains problematic (Baker \& Sutton 1997), what generally inducesa low number of samples. $T$ us, to make our sample more meaningful, by the criteria of commonness, we selected trees of the most common species present in a $500-\mathrm{m}^{2}$ plots, in a plateau area. $\mathrm{T}$ ese species belong mainly to families with greatest species richness and importance value, Lecythidaceae and Sapotaceae (O liveira et al. 2008) and al so to Caryocaraceae.

Insuf cient replication due canopy access dif culties generally induces inappropriate collection of pseudoreplicated data, a problem that has not yet received suf cient attention amongst canopy researchers (Barker 1997). To avoid pseudoreplication and to represent better the variability within trees, at each tree we collected composite samples, that consist of the sum of $f$ ve branch sub-samples. $T$ e branch surface area was determined by its length $\mathrm{x}$ width in meters def ning canopy $f$ ne litter unit as grams of litter mass per branch surface area $\left(\mathrm{g} \cdot \mathrm{m}^{-2}\right)$. To quantify $f$ ne litter accumulated on soil surface, we also collected f ve sub-samples (summing a composite sample) under the crown area of each tree sampled for canopy litter, using a $20 \times 20 \mathrm{~cm}$ aluminum frame. Each composite sample was sorted into six components - leaves, wood $<2 \mathrm{~cm}$, reproductive parts (i.e., fruits and fowers), bryophytes, roots and miscellaneous - and than oven-dried at $60^{\circ} \mathrm{C}$ for 50 hours (or until constant weight) and weighed. $\mathrm{T}$ ewind speed $\left(\mathrm{m} . \mathrm{s}^{1}\right)$ was recorded at each 30 minutes during the 2008 year by sonic anemometers (for details, see Araújo et al. 2002) located in a f ux tower at two heights: above the canopy $(60 \mathrm{~m})$ and in the sub-canopy $(28 \mathrm{~m})$.

$T$ enonparametric Two SampleW ilcoxon Rank Sum test (W) was performed to compare the amount of accumulated litter in tree canopy with that on soil surface and also the annual mean wind speed amongst sub-canopy and above canopy. $D$ if erences on amount of litter components within samples wereassessed by K ruskal-Wallis Rank Sum tests (KW ). All analyses were carried out using the free software $R$ 2.6.2 (R D evelopment CoreTeam 2008).

$T$ e mean canopy $f$ ne litter mass accumulated in the tree canopies was $294 \mathrm{~g} \cdot \mathrm{m}^{-2}$ of the branch surface area, with a large amplitude of variation (range $=79-677 \mathrm{~g}^{-\mathrm{m}^{-2}}$ ). $\mathrm{T}$ is largevariation can beexplained somehow by branch structural characteristics which had a general inf uence on canopy litter accumulation. $T$ e branch segments sampled covered a wide variation of branch width that exists within tree crowns ('pers. obs.'). In a Costa Rican C loud Forest, N adkarni \& M atelson (1991) found a mean canopy $f$ ne litter mass around 170 $\mathrm{g} \cdot \mathrm{m}^{-2}$ of the branch surface area (range $=4.5-1,268 \mathrm{~g} \cdot \mathrm{m}^{-2}$ ), which corresponded to $c a$. $1 \%$ of $f$ ne litter-layer mass on that area. T erefore, comparing these two forest formations, our study site in a Central Amazonian Tropical Rainforest area presents higher values of canopy $f$ ne litter mass than a C osta Rican Cloud Forest. $T$ ese results were somehow expected considering that (1) wind is one of the main within-canopy disturbances on canopy $f$ ne litter interception, besides rains and the impact of arboreal animal activities, and (2) winds are strongest and consequently a more important factor in the C osta Rican Cloud Forests than on Amazonian L owland 
Rainforests. In a Costa Rican Cloud Forest the wind speed above the canopy range between 18 and $180 \mathrm{~m} \cdot \mathrm{s}^{1}$ ( $\mathrm{N}$ adkarni $\&$ M atelson 1991), while we detected a mean daily wind speed above canopy of 1.92 ( $\pm 0.90 \mathrm{SD}) \mathrm{m} . \mathrm{s}^{1}$ quite constant throughout the 2008 year (Figure 1b), for the plateau areas of our study site on $C$ entral Amazon, with its maximum values reaching $8.3 \mathrm{~m} . \mathrm{s}^{1}$.

$T$ e mean $f$ ne litter mass accumulated on soil surface in Central Amazonian Forest was 833 g. $\mathrm{m}^{-2}$ (8.33 t.ha' ${ }^{-1}$; range $\left.=567-1,385 \mathrm{~g} \cdot \mathrm{m}^{-2}\right)$. $\mathrm{T}$ is value fell in the range of another study in the samearea (M onteiro 2005) that found the highest amount of $f$ ne litter mass on soil surface in the plateau areas

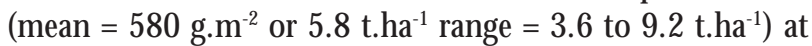
the end of the dry season, when higher amounts of litter are accumulated. Since we also sampled at the time of greatest litter accumulation (Luizão \& Schubart 1987), wefound high values of litter mass.

Evaluating vertical variation of litter accumulation, litter mass on forest $f$ oor dif ers signif cantly from canopy ( $W=$ $1 ; p<0.05$ - Figure 1a). It should be closely related to wind speed vertical stratif cation. W ind reaches higher speeds in the canopy than in lower forest strata; thereforewind is supposed to remove more litter from higher canopy branches. $T$ e annual mean wind speed in sub-canopy was about $0.3 \mathrm{~m} . \mathrm{s}$ ${ }^{1}$, which was 6.4 times slower than the above canopy wind speed (W =278155723; $p<0.001$ - Figure 1b). Even more, lower forest strata (i.e., sub-canopy and understory) may have a substantial cumulative contribution to the of $f$ nelitter accumulation at forest $f$ oor.

A detailed comparison of the f ne litter composition showed differences in the amounts of such component accumulated in the canopy ( $\mathrm{KW}=20.115 ; \mathrm{df}=5 ; \mathrm{p}<0.01$ ) and in soil surface ( $K W=25.739 ; d f=5 ; p<0.001$ - Figure 2). $T$ e wooden component with less than $2 \mathrm{~cm}$ diameter dominates the canopy litter (174 g. $\left.\mathrm{m}^{-2}\right)$ while leafy component predominate in soil surface litter (353 g. $\left.\mathrm{m}^{-2}\right)$, followed by wood component ( $\left.273 \mathrm{~g}^{\mathrm{m}} \mathrm{m}^{-2}\right)$. Branches and twigs are less susceptible than leaves to the inf uence of winds, facilitating the prevalence of wood components in the canopy. Leaves use to be the main $\mathrm{f}$ ne litter component on soil surface, and subject to high decomposition rate, contributing signif cantly to faster nutrient cycling process (Luizão 1989). C anopy leaf litter turnover time recorded for Costa Rican Tropical Forests was 2.8 years, twice that of leaf litter turnover time on soil (a)

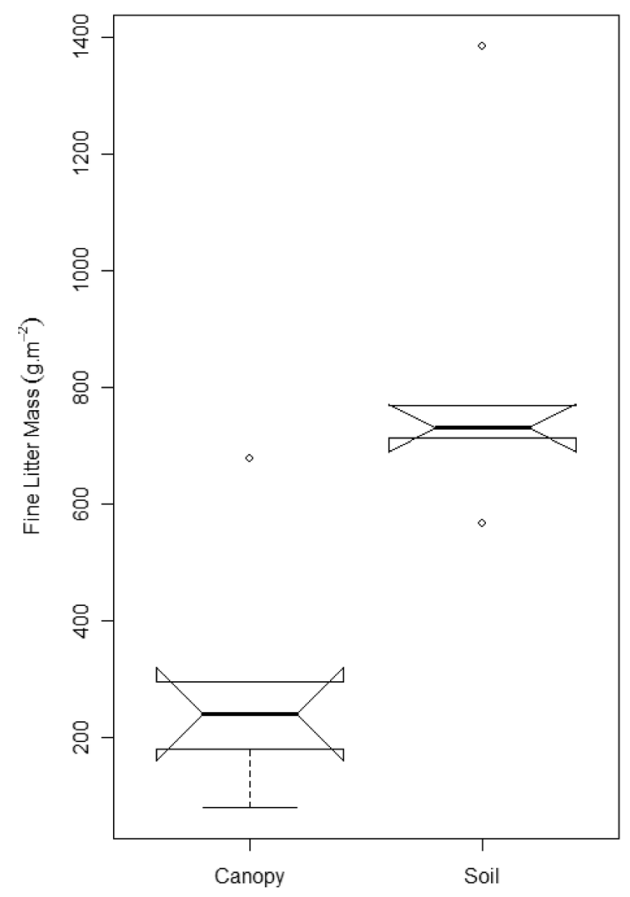

(b)

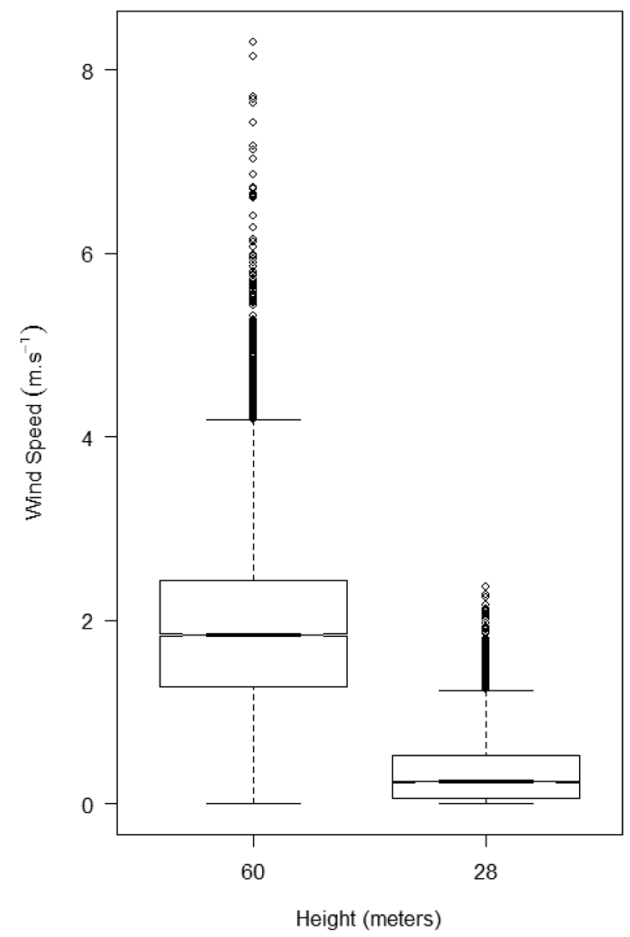

Figure 1 - Boxplots comparing (a) fine litter accumulated in canopy and on soil surface; (b) Wind speed (m. $\mathrm{s}^{-1}$ ) above the canopy (60 m) and in the sub-canopy $(28 \mathrm{~m})$ in Central Amazon Forest for the 2008 year. The box stretches from the lower to the upper hinges (defined as the $1^{\text {st }-3^{\text {th }}}$ quartiles) and the bold line shows the median of the data sample. The whiskers extend to the most extreme data point, which is no more than 1.5 times the interquartile range from the box. Open dots correspond to outlier data points that fall beyond 1.5 times the interquartile range. Notches in the boxes represent roughly a $95 \%$ confidence interval for the difference in two medians. Non-overlapping notches are strong evidence that the two medians differ significantly. 


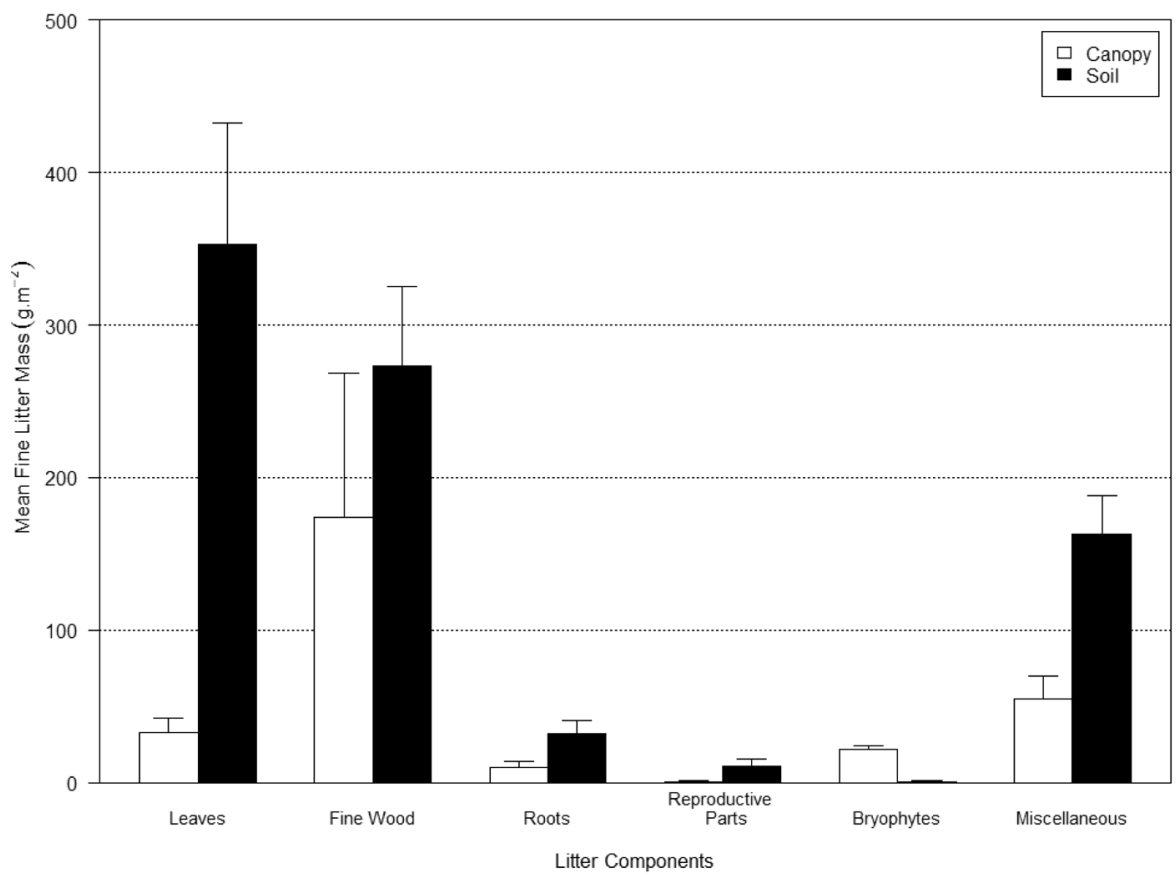

Figure 2 - Dry mass $\left(\mathrm{g} \cdot \mathrm{m}^{-2}\right)$ of litter components accumulated in canopy and on soil surface. Values in bars are means $(\mathrm{n}=5)$ and error bars represent standard errors.

surface that was 1.4 years (N adkarni \& M atelson 1991). T us, the few leaves that do remain in the canopy decomposeslower than on the soil. According to N adkarni \& Longino (1990), this low decomposition rate in the upper stratum should be attributed to drier environmental conditions and lower densities of key decomposers in thetree crowns. $0 \mathrm{n}$ theother hand, the bryophyte component of litter was found just in the canopy samples suggesting that its soft material is quickly decomposed in the canopies and do not reach the forest $f$ oor, at least in a recognizable way.

M ore detailed studies concerning long term $f$ ne litter turnover and decomposition rate in Amazonian tropical rainforestscanopy arestill needed and essential to increase our knowledge on nutrient cycling at dif erent forest layers and for further discussions on biosphere-atmosphere interactions. In thesame way, long term studies addressing dif erent vegetation types (primary and secondary forests) and topographic positions (i.e., plateau, slope and valley) are necessary to clarify the seasonal dynamic of canopy $f$ ne litter accumulation and to make comparisons between dif erent forest types possible.

Concluding, the studied Central Amazonian Rainforest intercepts greater $f$ ne litter mass in the canopy compared to other forest formations with higher winds speed, as in a Costa Rican Cloud Forest. $T$ e mean canopy $f$ ne litter mass accumulated at the end of the dry season was less than a half of that on soil surface. $T$ ef newood component dominates the canopy samplings suggesting a slower litter decomposition rate at this stratum.

\section{ACKNOWLEDGMENTS}

We are grateful to Tânia $M$. Sanaiotti, O livier Jaudoin, Cedric Billod and Julien Rousselet whom promote rope technique training through the $C$ anopy U niversal M ovement Techniques Course; to the LBA staf at Cuieiras Reserve for logistical support; to Lissandra Souza and Sr. O svaldo for help in thef eld and to Ítalo M ourthé, $\mathrm{H}$ enriqueN ascimento and two anonymous reviewers for helpful suggestions on the manuscript. Financial support was provided by the Large ScaleBiosphere-AtmosphereExperiment in Amazonia (LBA/ IN PA), Long Term Ecological Research Program (LTER/ PELD), CN Pq, Angelim Association, and Fundação de Amparo à Pesquisa do Estado do Amazonas (FAPEAM ).

\section{LITERATURE CITED}

Alvarez-Sanchez, J.; Guevara, S. 1999. Litter interception on Astrocaryum mexicanum Liebm. (Palmae) in a tropical rain forest. Biotropica, 31: 89-92.

Araújo, A.C.; N obre, A.D.; Kruijt, B.; Elbers, J.A.; Dallarosa, R.; Stefani, P.; von Randow, C.; M anzi, A.O.; Culf, A.D.; Gash, J.H.C.; Valentini, R.; Kabat, P. 2002. Comparative measurements of carbon dioxidef uxes from two nearby towers 
in a central Amazonian rainforest: T eM anaus LBA site. Journal of Geophysical Research, 107: 8090-8110.

Baker, M.G. 1997. An update on lower tech methods for forest canopy access and on sampling a forest canopy. Selbyana, 18: 16-26.

Baker, M .G .; Sutton, S.L. 1997. Low-tech methodsfor forest canopy access. Biotropica, 29: 243-247.

D earden, F.M .; Wardle, D.A. 2008. T e potential for forest canopy litterfall interception by a dense fern understorey, and the consequences for litter decomposition. Oikos, 117: 83-92.

Leopoldo P.R.; Franken W.; Salati E.; Ribeiro, M .N . 1987. Towards a water balance in the central Amazonian region. Experientia, 43: $222-233$.

Lowman, M .D .; W ittman, P.K. 1996. Forest canopies: M ethods, hypotheses, and future directions. Annual Review of Ecology and Systematics, 27: 55-81.

Luizão, F.J. 1989. Litter production and mineral element input to the forest f oor in a Central Amazonian Forest. GeoJournal, 19: 407-417.

Luizão, F.J.; Schubart, H.O.R. 1987. Litter production and decomposition in 'terra f rme' forest of the central Amazonia. Experientia, 31: 281-285.

M onteiro, M.T.F. 2005. Carbon dynamics and litter nutrients interactions between 'Terra Firme' forest and stream in Central Amazonia. D issertação de M estrado, Instituto N acional de Pesquisas da Amazônia/Fundação Universidade do Amazonas, M anaus, Amazonas. 93 pp (in Portuguese).
Nadkarni, N.M.; Longino, J. 1990. Density and composition of macroinvertebrates in canopy and forest f oor organic matter in a neotropical cloud forest. Biotropica, 22: 286-289.

N adkarni, N .M .; M atelson, T.J. 1991. Finelitter dynamics within the tree canopy of a Tropical Cloud Forest. Ecology, 72: 2071-2082.

N adkarni, N .M .; Schaefera, D .; M atelson, T.J .; Solano, R. 2004. Biomass and nutrient pools of canopy and terrestrial components in a primary and a secondary M ontane Cloud Forest, C osta Rica. Forest Ecology and Management, 198: 223-236.

Oliveira, A.N .; Amaral, I.L.; Ramos, M .B.P.; N obre, A.D .; Couto, L.B.; Sahdo, R.M . 2008. Composition and foristic-structural diversity of a hectare of 'terra $\mathrm{f}$ rme' dense forest in Central Amazonia, Amazonas, Brazil. Acta Amazonica, 38: 627-642 (in Portuguese, with abstract in English).

Proctor, J. 1983. Tropical Forest litterfall. I: Problems of data comparision, p. 267-273. In: Sutton, S.L.; W hitemore, T.C.; Chadwick, A.C. (Eds). Tropical Rain Forest: Ecology and Management. Scientif c Publications, Oxford, England.

R D evelopment CoreTeam. 2008. R: a language and environment for statistical computing. R Foundation for Statistical Computing, Vienna. http://www.R project.org

Recebido em 30/03/2010

Aceito em 04/08/2010 
